IZA DP No. 5132

A Distributional Analysis of the Public-Private Wage Differential in India

Mehtabul Azam

Nishith Prakash

August 2010 


\title{
A Distributional Analysis of the Public-Private Wage Differential in India
}

\author{
Mehtabul Azam \\ World Bank \\ and IZA \\ Nishith Prakash \\ Cornell University, \\ CReAM and IZA
}

\author{
Discussion Paper No. 5132 \\ August 2010 \\ IZA \\ P.O. Box 7240 \\ 53072 Bonn \\ Germany \\ Phone: +49-228-3894-0 \\ Fax: +49-228-3894-180 \\ E-mail: iza@iza.org
}

\begin{abstract}
Any opinions expressed here are those of the author(s) and not those of IZA. Research published in this series may include views on policy, but the institute itself takes no institutional policy positions.

The Institute for the Study of Labor (IZA) in Bonn is a local and virtual international research center and a place of communication between science, politics and business. IZA is an independent nonprofit organization supported by Deutsche Post Foundation. The center is associated with the University of Bonn and offers a stimulating research environment through its international network, workshops and conferences, data service, project support, research visits and doctoral program. IZA engages in (i) original and internationally competitive research in all fields of labor economics, (ii) development of policy concepts, and (iii) dissemination of research results and concepts to the interested public.
\end{abstract}

IZA Discussion Papers often represent preliminary work and are circulated to encourage discussion. Citation of such a paper should account for its provisional character. A revised version may be available directly from the author. 
IZA Discussion Paper No. 5132

August 2010

\section{ABSTRACT}

\section{A Distributional Analysis of the Public-Private Wage Differential in India*}

We investigate the public-private wage differential in India using nationally representative micro data. While the existing literature focuses on average wage differential, we study the differences in the wage distributions. The raw wage differential between public and private sector is positive across the entire distribution for both genders irrespective of area of residence. A quantile regression based decomposition analysis reveals that the differences in observed characteristics (covariate effect) account for only a small part of the wage differential at lower quantiles, but a larger part at higher quantiles. At the very top of the distribution, covariate effect account for a majority of the observed wage differential.

JEL Classification: J3, J45

Keywords: quantile regression, public-private wage differential, India

Corresponding author:

Nishith Prakash

Charles H. Dyson School of Applied Economics and Management

Cornell University

Ithaca, NY 14853-7801

USA

E-mail: nishith.prakash@cornell.edu

\footnotetext{
* We thank Edward Hoang, Aparajita Singh for helpful comments and discussion. The findings and opinions expressed here are entirely those of the authors and do not necessarily represent those of the World Bank.
} 


\section{Introduction}

Public sector employees pay is an important area of empirical research in developed and industrialized nations. Public sector pay has persistently garnered policy attention given its size and its implication for fiscal policy in developed countries. Early works comparing the earnings of public sector employees in the United States was undertaken by Smith (1976 and 1977). She found that rates of pay were higher for public sector employees than private sector employees, and the wage premium was larger for female than for male public sector employees. Bender (1998) and Gregory and Borland (1999) survey the current literature on public-private wage differentials and report that central governments pay more on average than the private sector, even after controlling for differences in productivity characteristics. For example, federal government workers earn between $5 \%$ and $30 \%$ more than their privatesector counterparts in the United States. Katz and Krueger (1993) offer several institutional and political reasons for the gap in wages between public and private sector employees. Governments are a large employer and therefore place an upward bias on wages; there are regional inflexibilities due to nationwide pay scales; there is a lack of a profit motive; there is a higher union coverage; and political considerations such as voters opposed to paying public sector officials high salaries. Reder (1975) and Bojras (1980) conjecture that politicians pay bureaucrats to produce votes for them so politicians remain in office.

In contrast, the understanding of public-private wage differentials has received less attention despite the size of public sector in India. The government remains, by far, the largest employer in India. The paucity of evidence on the public-private wage differentials for the Indian labor market is usually attributed to the limited availability of data. The first set of evidence refers back to the early 1980s, where a number of studies (Duraiswamy and Duraiswamy, 1995; Madheswaran, 1998, Lakshmanasamy and Ramasamy, 1999; Madhewaran and Shroff, 2000) use the survey of Degree Holders and Technical Personnel (DHTP) conducted along with the 1981 Census of India. They find that on the average, wages in the private sector was higher than the public sector. However, the evidence from the 1990s show 
conflicting findings. Data on wages from the 1997-98 Annual Survey of Industries (ASI), which covers the factory sector, suggest that the public sector offers higher remuneration to workers compared to the private sector (Glinskaya and Lokshin, 2007). Using the National Sample Survey (NSS) datasets for 1993-94 and 1999-00, Glinskaya and Lokshin explore public-private wage differential in India using OLS and propensity score matching methods. They find that that the public sector wage premium in 1999 ranges from 62 to 102 per cent (depending on the choice of the methodology). Also, the wage differentials tend to be higher in rural areas compared to urban areas, are higher among women than among men, and higher among low-skilled workers compared to high-skilled workers.

The wage premium enjoyed by the public sector in India is not surprising as in most cases the public sector wants to be a good employer and may be willing to pay higher wages to its employees. While the wage in the private sector is determined based on profit considerations, the wages in public sector continue to be decided by the government. The central government sets wages for the public sector employees through the Pay Commission (constituted at certain intervals), which is a central body at the federal level. The Pay Commission in India tries to maintain the ratio between the minimum pay scale and per capita income. There are growing perceptions that because of globalization and fast economic growth experienced in the last two decades, public sector jobs have become less attractive relative to comparable private sector jobs. ${ }^{1}$ Unfortunately, there exist no empirical evidences to back this perception.

The existing set of evidence from India fails to answer two important questions. First, is the advantage of being employed by the public sector equal across the entire wage distribution or only at the tails of the wage distribution? Second, does the perception that government jobs pay less for the same high ranking jobs which receive higher pay in the private sector have merit? It is generally believed that as a good employer the public sector may be willing

\footnotetext{
${ }^{1}$ A large number of memoranda to Sixth Pay Commission, particularly those pertaining to group A employees (higher level jobs), have mentioned the disparities between the private sector salaries and salaries in the government, citing this as a reason for the reduced attractiveness of the government jobs as a career option and for the decline in the quality of intake (Government of India, 2008).
} 
to pay lower-skilled workers more, while the government might be reluctant to offer higher wages to high-skilled workers, as the public may not want public servants to earn more than comparably trained and experienced private-sector counterparts (Katz and Krueger, 1993). Also, it is important for policy makers, who wish to align the public wages with the private sector by increasing or slowing the relative rate of public sector wage growth, to know how the wage distributions differ between the two sectors. ${ }^{2}$ Aligning the average rates of pay will be misleading if the wage distributions between public and private sector differ significantly. Evidence from other countries suggest that the distributions do differ, as found in the double imbalance concept articulated by Schager (1993), Katz and Krueger (1993), and Elliot and Duffus (1996). This imbalance is characterized by public sector workers at the lower end of the wage distribution receiving the largest wage premium, while the public sector workers at the top end of distribution earn less than their private sector counterparts. If the Indian experience is also similar to this (as claimed by group A employees-top end public sector employees-in their memoranda to Sixth Pay Commission), then policies aimed at aligning the wage structures at the top of the distribution should be followed.

In this paper, using the 61st round of National Sample Survey Organization (NSSO) ${ }^{3}$ data (2004-05) from India, we compare the wage distributions of public and private sector to find out whether there exist major differences at opposite tails of the distribution. First, we document the existence of wage differential between public-private sector in India across the entire distribution by gender and area of residence. Second, we look at what explains the existing wage differential between the two sectors. For this we use a quantile regression based decomposition technique proposed in Machado and Mata (2005, MM henceforth). Given the heterogeneity in public-private wage differential observed in the data, the MM technique is a natural choice since it is well suited to capture the heterogeneity in the coefficient and

\footnotetext{
${ }^{2}$ It is undeniable that public sector jobs provide unparalleled job security, pension benefits, work-life balance and status. The prestige involved in working for the government and the opportunity of making a contribution to national policy or its implementation are other aspects which add an unquantifiable value to government jobs (Government of India, 2008)

${ }^{3} \mathrm{NSSO}$ conducts large scale (called quinquennial rounds) nationally representative survey at five-year intervals. The latest quinquennial round (61st round) was collected in 2004-05.
} 
covariates across the entire distribution. Our study is the first, to the best of our knowledge which examines the differences in public private wage distributions in India. ${ }^{4}$

Our main findings are as follows. First, the public sector workers earn more than private sector workers across the entire distribution, irrespective of area of residence and gender; also, there is no evidence of double imbalance in India. Second, the differences in characteristics (covariate effect) account for only a small part of the wage premium enjoyed by public sector employees at the lower part of the distribution; however, the contribution of covariate effect increases at the higher quantile, and at the top of the distribution differences in covariates account for majority of wage differential. Third, the averages mask a great deal of heterogeneity not only in the raw wage gap observed, but also in the coefficient and covariate effects.

This paper is organized as follows. Section 2 discusses the empirical strategy, section 3 describes the data, section 4 presents the results, and section 5 concludes.

\section{Empirical Methodology: Decomposing the Wage Gap}

We use the MM technique to decompose the wage gap between public and private sector at each percentile into two components - one due to the differences in distribution of covariates and the other due to differences in the returns to those covariates. The MM technique combines quantile regressions with bootstrap methods to generate distributions which confirm to the specified model. The decomposition involves creating three distributions of log wageprivate, public, and counterfactual. The private (public) distribution of log wage is estimated using private (public) covariates and private (public) returns to those covariates. The private and public distributions are denoted as $F\left(w^{P v t} \mid X^{P v t}, \beta^{P v t}\right)$ and $F\left(w^{P u b} \mid X^{P u b}, \beta^{P u b}\right)$ respectively, where $w$ is log wage, $X$ is the covariate matrix, and $\beta$ is the vector of returns to

\footnotetext{
${ }^{4}$ Evidence from many other countries-for example Canada (Mueller 1998), UK (Disney and Gosling 1998), Zambia (Nielsen and Rosholm 2001), and Germany (Melly, 2005a)-suggest that the least squares estimate of the mean public sector wage premium gives an incomplete picture of the conditional distribution.
} 
those covariates. ${ }^{5}$ The counterfactual distribution, $F\left(w^{*} \mid X^{P v t}, \beta^{P u b}\right)$, is the distribution of log wage that would exist if workers were endowed with the characteristics of private sector employees but received public sector returns to those characteristics.

Following Albrecht et al. (2003) adaption of MM technique, the three distributions are generated as follows: First, for public and private sector, we estimated quantile regression coefficient at each percentile, i.e., $\widehat{\beta}^{P v t}\left(\theta_{i}\right)$ and $\widehat{\beta}^{P u b}\left(\theta_{i}\right)$, where $\theta_{i}=[0.01,0.02, \ldots, 0.98,0.99]$. Second, we draw $m=1000$ random draws from the distribution of covariates ( $X$ matrix) for each $\widehat{\beta}\left(\theta_{i}\right)$ and stack $X^{\prime} \widehat{\beta}$ to get the desired distribution. ${ }^{6}$ To get the counterfactual $F\left(w^{*} \mid X^{P v t}, \beta^{P u b}\right)$, the $\widehat{\beta}^{P u b}$ is estimated using the sample of public sector employees while the random draws are taken from the sample of private sector emplyees' covariate matrix $\left(X^{P v t}\right)$.

The decomposition consists of comparing the counterfactual wage distribution with the wage distribution of public and private sector. Let $w^{P u b}$ and $w^{P v t}$ denote the empirical wage distribution in public and private sector, respectively. We may decompose the differences in the wage distributions at each quantile $\theta \in(0,1)$ as:

$$
\begin{aligned}
w_{\theta}^{P u b}-w_{\theta}^{P v t} & =F_{\theta}\left(w^{P u b} \mid X^{P u b}, \beta^{P u b}\right)-F_{\theta}\left(w^{P v t} \mid X^{P v t}, \beta^{P v t}\right)+\text { residual } \\
& =\left\{F_{\theta}\left(w^{P u b} \mid X^{P u b}, \beta^{P u b}\right)-F_{\theta}\left(w^{*} \mid X^{P v t}, \beta^{P u b}\right)\right\}+ \\
& \left\{F_{\theta}\left(w^{*} \mid X^{P v t}, \beta^{P u b}\right)-F_{\theta}\left(w^{P v t} \mid X^{P v t}, \beta^{P v t}\right)\right\}+\text { residual }
\end{aligned}
$$

The wage gap between public and private sector consists of the covariate effect, which is the first term on the right hand side, and the coefficient effect which is the second term on the right hand side of equation 1 . The residual is the difference unaccounted by the estimation method (estimated as the difference between the total difference estimated using the empirical wage distributions of public and private sector and the difference estimated using the estimated marginal distributions for public and private sector, i.e., $F\left(w^{P u b} \mid X^{P u b}, \beta^{P u b}\right)$ and

\footnotetext{
${ }^{5}$ The generated public and private wage distributions confirm to the specified model.

${ }^{6}$ We will end up with 99,000 observations for $w_{i}^{\star}$.
} 
$F\left(w^{P v t} \mid X^{P v t}, \beta^{P v t}\right)$, respectively). The residual term comprises the simulation errors which disappears with more simulations, the sampling errors which disappears with more observations and the specification error induced by estimating linear quantile regression (Melly, $2005 b)$.

\section{Data}

We use nationally representative household survey data from the Employment and Unemployment Schedule, administered by the National Sample Survey Organization (NSSO), Government of India. For this study we use data from 61st round of the NSSO conducted in 2004-05. The data contains information on household size and composition, social group, religion, monthly consumption, landholdings, demographic variables (age, gender, marital status), educational participation and attainment, and a detailed employment section on principal and subsidiary activities (industry, occupation, wages earned). The sample of households is drawn based on a stratified random sampling procedure and all the analysis is done using survey weights.

In the data, workers are classified as self-employed, regular wage/salaried and casual labor. Weekly wages earned (both cash and in-kind) are reported at current prices for regular wage/salaried and casual labor. ${ }^{7}$ We define total wages as sum of weekly cash and in-kind wages from the principal activity. We divide the total wages by number of hours worked in reference week to get the hourly wage rate. The survey also asks all the workers to categorize their place of main work activity in eighth categories: proprietary male, proprietary female, partnership with members from same household, partnership with members from different household, government/public sector, public/private limited company, co-operative societies/trust/other non-profit institutions, and employer's households (i.e., private house-

\footnotetext{
${ }^{7} \mathrm{~A}$ regular wage salaried worker is a person who works in others' farm or non-farm enterprises (household and non-household) and in return received salary or wages on a regular basis; while a casual worker is a person who is engaged in others' farm or non-farm enterprises (household and non-household) and in return, received wages according to the terms of the daily or periodic work contract.
} 
holds employing maid servant, watchman, cook, etc.). Government/public sector was treated as public sector while the others are grouped into private sector. Since majority of the public sector employment is in regular salaried, we restrict our sample to regular salaried workers of age 21-60. Around 4.51\% of regular workers in age group 21-60 do not report the enterprise type. Those workers are dropped from the analysis. As the sample is restricted to regular wage earners, the results must be interpreted conditional on selected sample. Issues of sample selection bias and the potential problem of endogeneity of sector choice are considered outside the scope of the present paper, we only concentrate on distributional aspects.

Our dependent variable is log of hourly wage and explanatory variables include age, age square, dummies for states, education levels, female, married, scheduled castes (SCs), scheduled tribes (STs), other backward castes (OBCs), occupation and industry. The SCs, STs and OBCs are the disadvantaged groups, and enjoy affirmative policies in India. ${ }^{8}$ Table 1 presents the descriptive statistics of variables included in the covariate matrix (dummies for states are included in $X$ matrix but are not reported in the table). Mean of relevant variables show that average hourly earnings are higher in the public sector than private sector for both sexes and for both rural and urban areas. They also show that public sector employees have higher educational attainment than the private sector employees. For example, in urban India, $39 \%$ of male and $48 \%$ of female public sector employees have tertiary education, while only $17 \%$ of male and $27 \%$ of female private sector employees have tertiary education. In rural India also, $27 \%$ of male and $21 \%$ of female public sector employees have tertiary education, while only $21 \%$ of male and $13 \%$ of female private sector employees have tertiary education. Public sector employees are on average older than private sector employees, and they are more likely to be in professional or clerical jobs, while the private sector workers are more likely to be in production related activities.

Figure 1 and Figure 2 plot the kernel density of the log of hourly wages for both genders for urban and rural areas, respectively. The kernel density figures show that the wage

\footnotetext{
${ }^{8}$ see Prakash 2009, Chin and Prakash 2010, and Bertrand, Hanna and Mullainathan (2010) for discussion on impact of affirmative action policies in India.
} 
distribution is quite distinct between the two sectors. For both gender, the public sector earnings distribution is characterized by a higher density function around the mode and lower dispersion in urban sector, however, in rural sector, the public sector female workers wage distribution shows bimodality. The public sector earnings lies right of private sector earnings indicating that public sector employees are paid higher across the distribution in both rural and urban sector. This is true for both males and females. Figure 3 plots the log of wage differential between public sector and private sector employees. Public sector employees at the 5th quantile of the public sector earnings distribution enjoy an earnings advantage over private sector employees at the same point in the private sector distribution of wages; the same holds true for employees at the 95th quantile of the public sector and private sector earnings distribution. Public sector pays better than private sector for both genders in both urban and rural areas at each part of the distribution. In urban areas, female public sector employees have higher wage premium than the male public sector employees. In rural areas, the public sector wage premium is smaller for female workers compared to male workers in lower half of the distribution, however, in the top part of the distribution, female public sector workers earn more premium than male public sector workers. The comparison of public and private wage distributions shows that the advantage held by public sector employees is held across the distribution, and there is no evidence of "double imbalance" in India. In the next section, we explore what explains the wage premium enjoyed by the public sector employees?

\section{Results}

The MM decomposition divides the wage differential between public and private sector employees at each percentile into coefficient and covariate effects. The covariate effect refers to the differential which can be attributable to the differences in observed characteristics, while the coefficient effect refers to differential which can be attributed to difference in prices 
paid to same characteristics. Figure 4 and Figure 5 plot the coefficient and the covariate effects with $95 \%$ confidence intervals for urban and rural areas, respectively. Table 2 report the decomposition results for the selected quantiles. The $95 \%$ bootstrap confidence interval are the quantiles $2.5 \%$ and $97.5 \%$ of the distribution of the relevant statistic obtained by bootstrap with 1000 replications.

In urban India, male workers earn $87 \%$ more on average in public sector than in private sector. Similarly, the female workers in public sector earn $125 \%$ more on average compared to private sector female workers. However, the average premium enjoyed by public sector employees masks a great deal of heterogeneity observed in wage premium enjoyed by public sector employees. For example, at the 10th percentile, male (female) public sector workers earn 105\% (135\%) more than the private sector workers; at the 50th percentile, male (female) public sector workers earn 105\% (161\%) more than the privates sector workers; and at the 90th percentile, the male (female) public sector workers earn 60\% (64\%) more than the private sector workers. Thus the public sector workers earn more across the entire wage distribution, and the advantage enjoyed by female public sector workers over private sector female worker is larger than the advantage enjoyed by male public sector workers over private sector male workers.

Traditional Oaxaca-Blinder (OB) decomposition reveals that the unexplained part (coefficient effect or price differential) is $58 \%$ and $54 \%$ of the wage differential enjoyed by public sector male and female workers. Hence, although the public sector workers have better characteristics, it fails to explain the differences completely as more than half of the differences are explained by the price differential, i.e., workers with same characteristics are paid better in public sector compared to private sector. MM decomposition brings out the heterogeneity in the coefficient and covariate effects, which was not captured by OB decomposition. MM decomposition tell us that at the 10th percentile, the coefficient effect explains $77 \%$ (54\%) of wage differential between public and private sector male (female) workers. At the 50th percentile, the coefficient effect explains $59 \%$ (49\%) of wage differential between public and 
private sector male (female) workers. Similarly, at the 90th percentile, the coefficient effect explains $21 \%(25 \%)$ of wage differential between public and private sector male (female) workers.

Thus for male workers in public sector in urban areas, the coefficient (covariate) effect is large (small) at the lower quantiles and declines (increases) at higher quantiles. At the very top of the wage distribution, the covariate effect contributes to almost all the price differential. The pattern is the same for both genders, and the monotone decrease of the public sector price differential as we go from the lowest to the highest quantiles appears clearly in Figure 4. However, the price differential remains positive across the whole distribution. This is in contrast to the evidences from many countries where price differential is positive at lower half of the distribution and negative at the top end of the distribution. For female workers in urban areas, the gap between coefficient and covariate effect is not as large as it is for male workers at lower quantiles. A large part of wage differential enjoyed by female workers is because of superior characteristics of public sector workers. The residual component is around zero for male workers implying that the specified linear models work fairly well. In case of female workers, the residuals account for some of the wage differential.

In case of rural India, the average wage differential between public and private sector workers conceals a great deal of heterogeneity. For example, the male public sector workers earn $87 \%$ more at an average, however, this wage premium of male public sector workers is $58 \%$ at the 10 th quantile, $100 \%$ at the 50 th quantile, and $69 \%$ at the 90 th quantile. Although similar to urban areas, public sector workers earn considerable wage premium compared to private sector workers, there exists few differences between urban and rural areas. First, although the male public sector workers earn a similar wage premium in both areas, wage premium earned by female public sector workers is much lower in rural areas than in urban areas. Also, the female public sector workers in lower half of the wage distribution earn far less wage premium than the male public sector workers in rural areas. In contrast, the female public sector workers earn much higher wage premium than male public sector workers in 
urban areas (see Figure 3).

In rural India, the coefficient effect contributes to $63 \%$ (45\%) of the average wage premium enjoyed by male (female) public sector workers. However, once again the MM decomposition brings out the heterogeneity in the coefficient and covariate effects across the entire distribution. For male public sector workers in rural areas, the coefficient effect dominates across the entire distribution except at the top of the distribution. The covariate effect is low at the bottom of the wage distribution and increases at the higher quantiles, and only at the top part of the wage distribution it outweighs the coefficient effect. The coefficient effect is very large at the middle of the distribution. For male workers in rural areas, the linear model does a reasonable job in predicting the wages at different quantiles; however, for female workers in rural areas, the linear model fails to predict wages within a reasonable deviation from the actual wages (residuals are large). Although we can infer that the coefficient and covariate both contribute to the wage gap observed between public and private sector female workers, it difficult to infer about relative importance of these two factors because of the presence of large residuals.

Overall, the findings suggest although the public sector workers are better endowed to comparable private sector workers, this only fails to explain the premium enjoyed by public sector workers. For similar characteristics a worker is paid more in public sector than in private sector, and although this premium decreases as we move to higher quantiles, it remains positive throughout the distribution. Hence, the belief that the public sector workers are paid less than private sector workers at the top of the distribution is misplaced as the empirical evidences do not support the belief.

\section{Conclusion}

In this paper, we examine the differences in the wage distributions between the public and private sector in India using the 61st round (2004-05) of NSSO data. The existing literature 
on public-private wage gap in India concentrates on averages and finds that average wage in public sector is higher than private sector in both urban and rural areas. Our paper is the first to study public-private wage differential in India across the entire distribution. We identify that public sector workers earn more than private sector workers across the entire distribution irrespective of the area of residence and gender. Using a quantile regression based decomposition technique proposed in Machado and Mata (2005), we find that price differential constitutes a major part of the advantage enjoyed by public sector employees, however, the price differential declines (covariate effect increases) as we move towards higher quantiles. At the very top of the distribution, almost all the wage differential is explained by better characteristics of public sector workers. Our study refutes the widely held view by government employees that they are underpaid compared to private sector employees. Hence the rationale for adjusting the public sector wages upwards is incorrect. Any upward revision of wages in public sector not only will lead to more wage gap compared to private sector but also will have a substantial impact on fiscal balance and inflation.

There are several qualifications and caveats to our results. First, although the survey asks the wages-in-kind, it is possible that the survey may have missed other benefits. Some of the private sector employees may have additional perquisites, but consensus is that it is generally less than the public sector (Glinskaya and Lokshin, 2007). In the absence of hard evidences, one can only speculate that the public-private wage differential may be larger once we quantify the perquisites. Second, it is extremely difficult to quantify the job security and status associated with public sector jobs. Job security would unambiguously add a lot to the benefits of public sector. We can only speculate that the public-private wage differential would be much larger once we account for these benefits. 


\section{References}

[1] Albrecht, J., Bjorklund, A. and Vroman, S. (2003), Is there a Glass Ceiling in Sweden?, Journal of Labor Economics, 21, 145-177.

[2] Aslam, M. and Kingdon, G. G. (2009), Public-private sector segmentation in the Pakistani labour market, Journal of Asian Economics, 20, 34-49

[3] Bender, K. A. (2003), Examining Equality between Public- and Private-Sector Wage Distributions, Economic Inquiry, 41, 62-79.

[4] Bender, K. A. (1998), The Central Government-Private Sector Wage Differential, Journal of Economic Surveys, 12, 177-220.

[5] Bertrand, M., Hanna, R. and Sendhil, M. (2010), Affirmative Action in Education: Evidence From Engineering College Admissions in India, Journal of Public Economics, 94 (1-2), 16-29.

[6] Bojras, G. J. (1980), Wage Determination in Federal Government: The Role of Constituents and Bureaucrats, Journal of Political Economy, 80, 1110-47.

[7] Chin, A. and Prakash, N. (2009), The Redistributive Effects of Political Reservation for Minorities: Evidence from India, IZA Discussion Paper, 4391.

[8] Duraiswamy, P. and Duraiswamy, M. (1995), Implications for Structural Reforms Public-Private Sector Wage Differential in India, Indian Journal of Labour Economics, 38(4), 597-602.

[9] Elliott, R.F. and Duffus, K. (1996), What Has Been Happening to Pay in the Public Sector of the British Economy? Developments over the Period 1970-1992, British Journal of Industrial Relations, 34, 51-85.

[10] Glinskaya, E. and Lokshin, M. (2007), Wage differentials between the public and private sectors in India, Journal of International Development, 19, 333-355. 
[11] Government of India (2008), Report of Sixth Pay Commission.

[12] Gregory, R. and Borland, J. (1999), Recent Developments in Public Sector labor Markets, in Handbook of Labor Economics, vol 3c, edited by Ashenfelter, O. and Card, D., Amsterdam: North-Holland, 3573-630.

[13] Katz, L. and Krueger, A. (1993), Public Sector Pay Flexibility: Labor Market and Budgetary Considerations, in Pay Flexibility in the Public Sector, Paris: OECD, 43-77.

[14] Koenker, R. and Bassett, G. (1978), Regression Quantiles, Econometrica, 46, 33-50.

[15] Lakshmanasamy, T. and Ramasamy, S. (1999), An Econometric Analysis of the Worker Choice between Public and Private Sector, Indian Journal of Labour Economics, 42(1), $71-83$.

[16] Machado, J. and Mata. J. (2005), Counterfactual Decomposition of Changes in Wage Distributions using Quantile Regression, Journal of Applied Econometrics, 20, 445-65.

[17] Madheswaran, S. (1998), Earning Differentials between Public and Private Sector in India, Indian Journal of Labour Economics, 41(4), 945-970.

[18] Madheswaran, S. and Shroff, S. (2000), Education, Employment and Earnings for Scientific and Technical Workforce in India, Indian Journal of Labour Economics, 43(1), $121-137$.

[19] Melly, B. (2005a), Decomposition of Differences in Distribution using Quantile Regression, Labour Economics, 12, 577-590.

[20] Melly, B. (2005b), Public-Private Sector Wage Differentials in Germany: Evidence from Quantile Regression, Empirical Economics, 30, 505-520.

[21] Oaxaca, R. (1973), Male-Female Wage Differential in Urban Labor Market, International Economic Review, 14, 693-709. 
[22] Prakash, N. (2009), Improving the Labor Market Outcomes of Minorities: The Role of Employment Quota, IZA Discussion Paper, 4386.

[23] Reder, M. (1975), The Theory of Employment and Wages in Public Sector, in Labor in Public and Non-Profit Sectors, edited by Hamermesh, D., Princeton University Press, $1-48$.

[24] Schager, N. (1993), An Overview and Evaluation of Flexible Pay Policies in the Swedish Public Sector, in Pay Flexibility in Public Sector, Paris: OECD, 113-24.

[25] Smith, S. (1976), Pay Differentials between Federal Government and Private Sectors Workers, Industrial and Labour Relations Review, 29, 233-257.

[26] Smith, S. (1977), Equal Pay in the Public Sector: Fact or Fantasy, Industrial Relations Section, Princeton 
Table 1: Descriptive statistics of sample

\begin{tabular}{|c|c|c|c|c|c|c|c|c|}
\hline & \multicolumn{4}{|c|}{ Urban } & \multicolumn{4}{|c|}{ Rural } \\
\hline & \multicolumn{2}{|c|}{ Male } & \multicolumn{2}{|c|}{ Female } & \multicolumn{2}{|c|}{ Male } & \multicolumn{2}{|c|}{ Female } \\
\hline & Public & Private & Public & Private & Public & Private & Public & Private \\
\hline Log of hourly wage & 3.53 & 2.66 & 3.32 & 2.07 & 3.17 & 2.31 & 2.31 & 1.65 \\
\hline Age & 43.09 & 33.88 & 40.48 & 35.38 & 41.99 & 34.18 & 37.08 & 35.86 \\
\hline Scheduled Castes & 0.17 & 0.13 & 0.18 & 0.21 & 0.21 & 0.18 & 0.16 & 0.25 \\
\hline Scheduled Tribes & 0.05 & 0.02 & 0.04 & 0.03 & 0.09 & 0.06 & 0.09 & 0.11 \\
\hline Other Backward Castes & 0.27 & 0.33 & 0.22 & 0.31 & 0.34 & 0.43 & 0.38 & 0.40 \\
\hline Below Primary & 0.06 & 0.15 & 0.09 & 0.37 & 0.09 & 0.25 & 0.14 & 0.53 \\
\hline Primary & 0.06 & 0.13 & 0.05 & 0.09 & 0.06 & 0.15 & 0.07 & 0.09 \\
\hline Middle & 0.12 & 0.20 & 0.04 & 0.09 & 0.14 & 0.20 & 0.13 & 0.09 \\
\hline Secondary & 0.15 & 0.16 & 0.10 & 0.08 & 0.20 & 0.15 & 0.20 & 0.07 \\
\hline Higher Secondary & 0.22 & 0.15 & 0.23 & 0.10 & 0.24 & 0.13 & 0.25 & 0.09 \\
\hline Graduate & 0.26 & 0.14 & 0.30 & 0.18 & 0.19 & 0.09 & 0.14 & 0.08 \\
\hline Post graduate & 0.11 & 0.05 & 0.17 & 0.08 & 0.08 & 0.03 & 0.06 & 0.04 \\
\hline Professional & 0.02 & 0.02 & 0.01 & 0.01 & 0.00 & 0.01 & 0.01 & 0.01 \\
\hline \multicolumn{9}{|l|}{ Occupation } \\
\hline Professional and technical & 0.21 & 0.11 & 0.52 & 0.26 & 0.34 & 0.11 & 0.63 & 0.21 \\
\hline Administrative, Managerial & 0.07 & 0.04 & 0.04 & 0.03 & 0.02 & 0.02 & 0.01 & 0.00 \\
\hline Clercial & 0.35 & 0.13 & 0.29 & 0.12 & 0.31 & 0.10 & 0.14 & 0.06 \\
\hline Sales & 0.00 & 0.15 & 0.00 & 0.03 & 0.01 & 0.10 & 0.00 & 0.02 \\
\hline Service Worker & 0.15 & 0.10 & 0.14 & 0.39 & 0.13 & 0.07 & 0.21 & 0.26 \\
\hline Farmers & 0.01 & 0.01 & 0.00 & 0.01 & 0.01 & 0.14 & 0.00 & 0.21 \\
\hline Production related workers & 0.21 & 0.47 & 0.01 & 0.17 & 0.18 & 0.46 & 0.01 & 0.25 \\
\hline \multicolumn{9}{|l|}{ Industry } \\
\hline Agriculture & 0.00 & 0.01 & 0.00 & 0.01 & 0.01 & 0.14 & 0.00 & 0.21 \\
\hline Mining & 0.04 & 0.18 & 0.01 & 0.11 & 0.03 & 0.13 & 0.01 & 0.20 \\
\hline Manifacturing & 0.06 & 0.24 & 0.01 & 0.09 & 0.01 & 0.18 & 0.00 & 0.06 \\
\hline Electricity and water supply & 0.05 & 0.03 & 0.01 & 0.01 & 0.07 & 0.03 & 0.01 & 0.00 \\
\hline Constuction & 0.01 & 0.22 & 0.00 & 0.05 & 0.01 & 0.16 & 0.01 & 0.04 \\
\hline Trade and hotels & 0.22 & 0.14 & 0.12 & 0.04 & 0.15 & 0.19 & 0.04 & 0.02 \\
\hline $\begin{array}{l}\text { Transport and communica- } \\
\text { tions }\end{array}$ & 0.45 & 0.06 & 0.28 & 0.06 & 0.35 & 0.03 & 0.15 & 0.01 \\
\hline Financial services & 0.16 & 0.06 & 0.55 & 0.29 & 0.36 & 0.10 & 0.79 & 0.26 \\
\hline Public and other services & 0.01 & 0.05 & 0.01 & 0.33 & 0.00 & 0.03 & 0.00 & 0.19 \\
\hline Number of observations & 7,661 & 10,178 & 1,834 & 2,863 & 7,200 & 5,555 & 1,591 & 1,055 \\
\hline
\end{tabular}




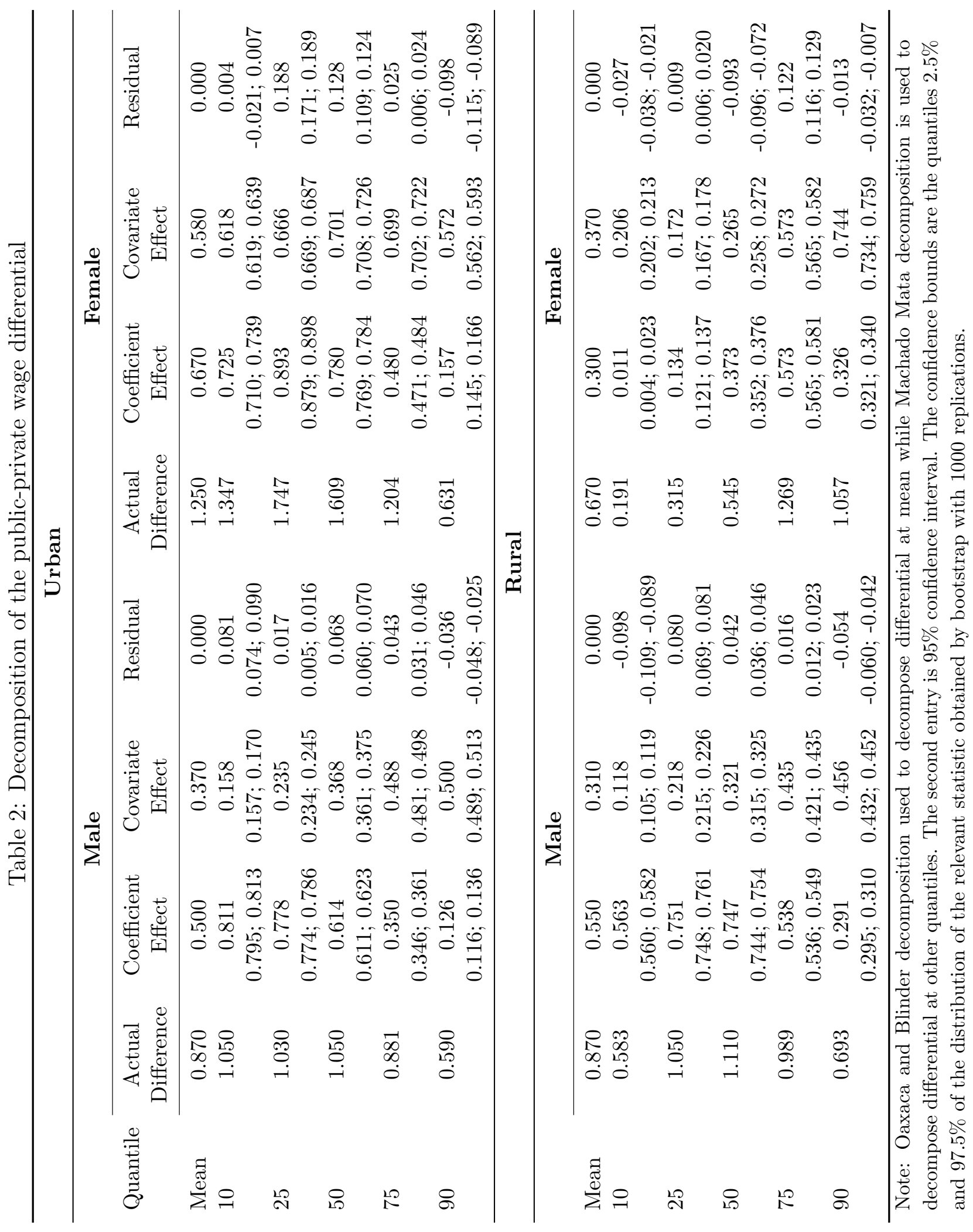


Figure 1: Kernel density of the wage distributions in Urban India

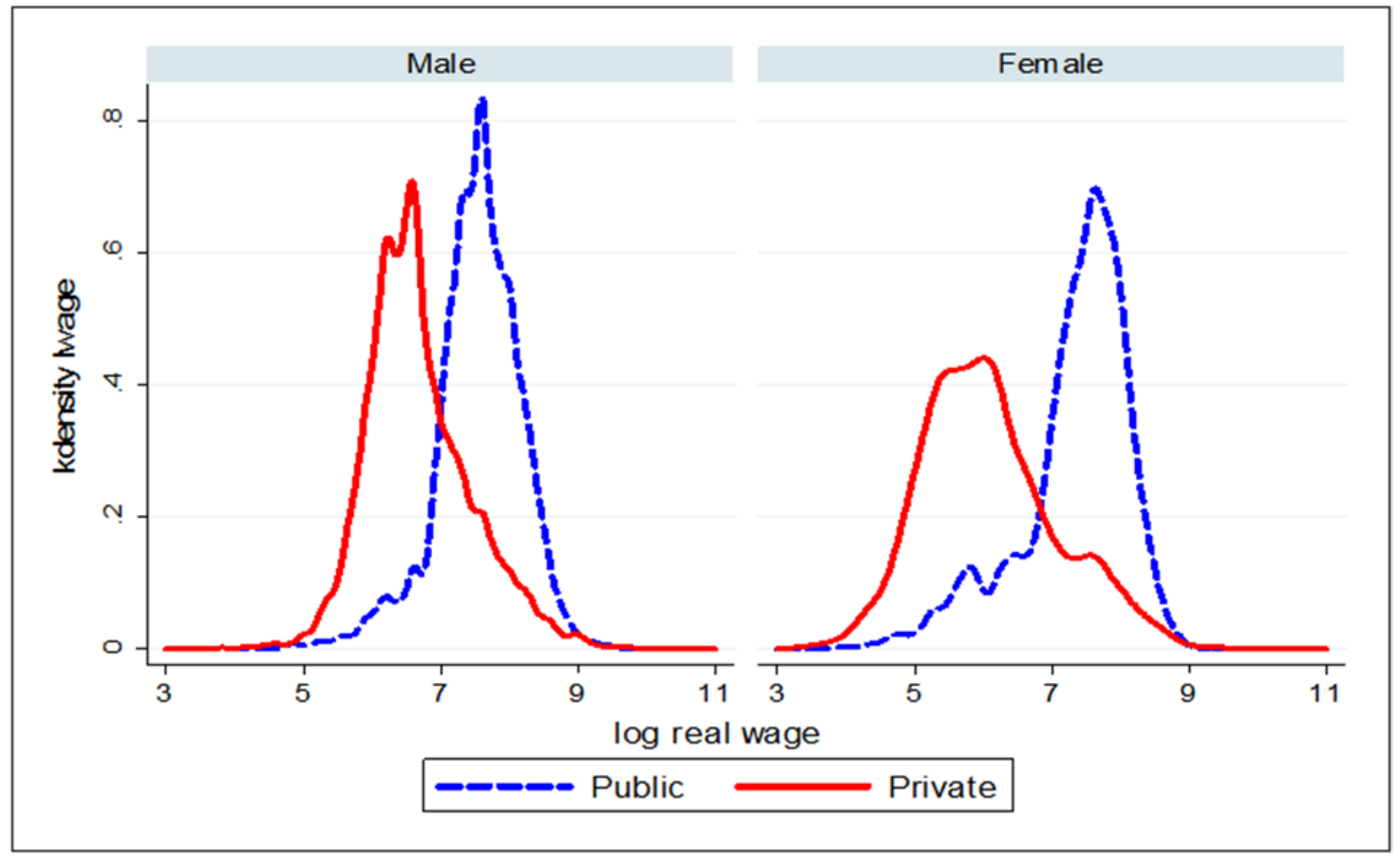

Figure 2: Kernel density of the wage distributions in Rural India

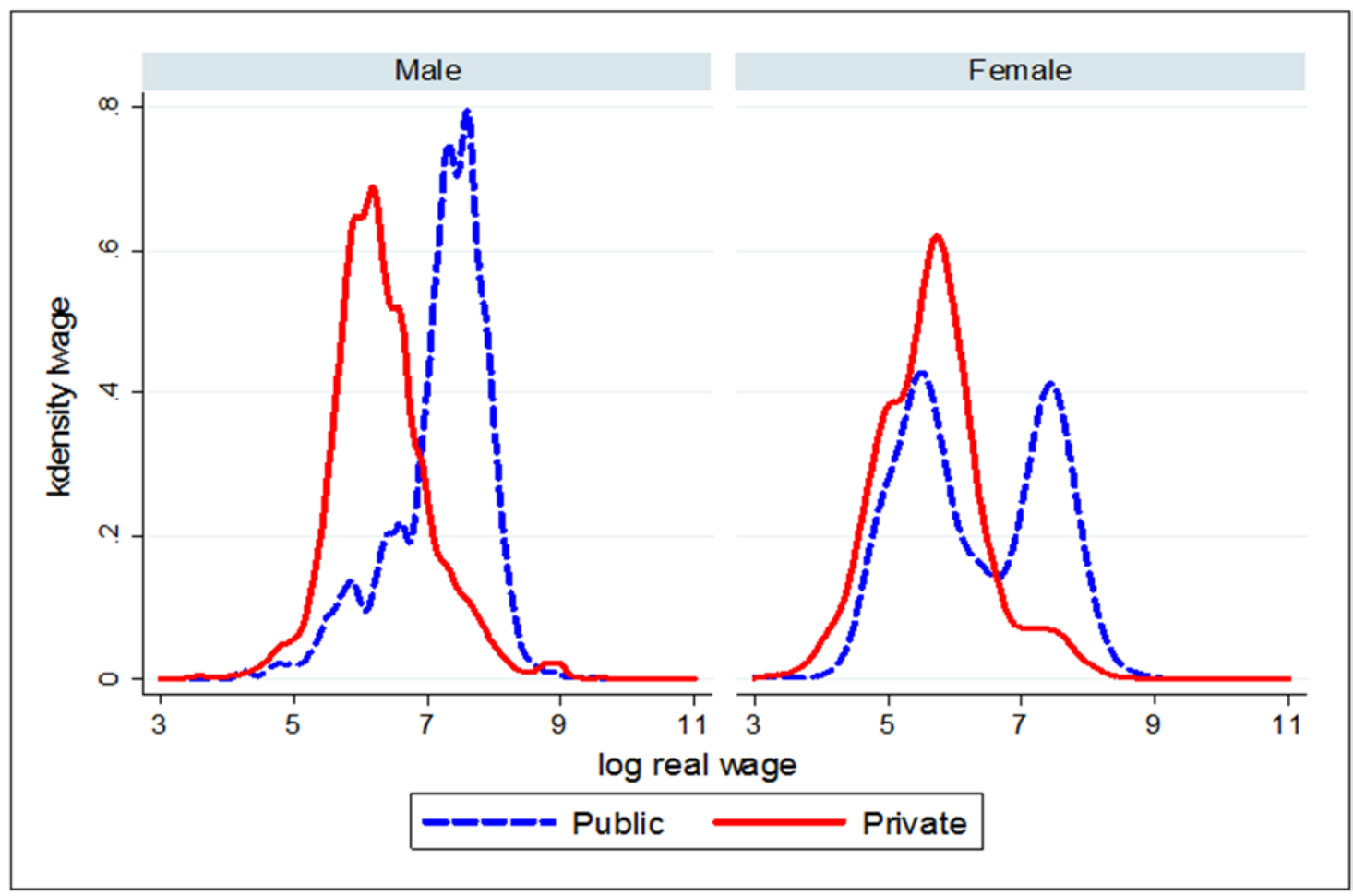


Figure 3: Wage differential between public and private sector
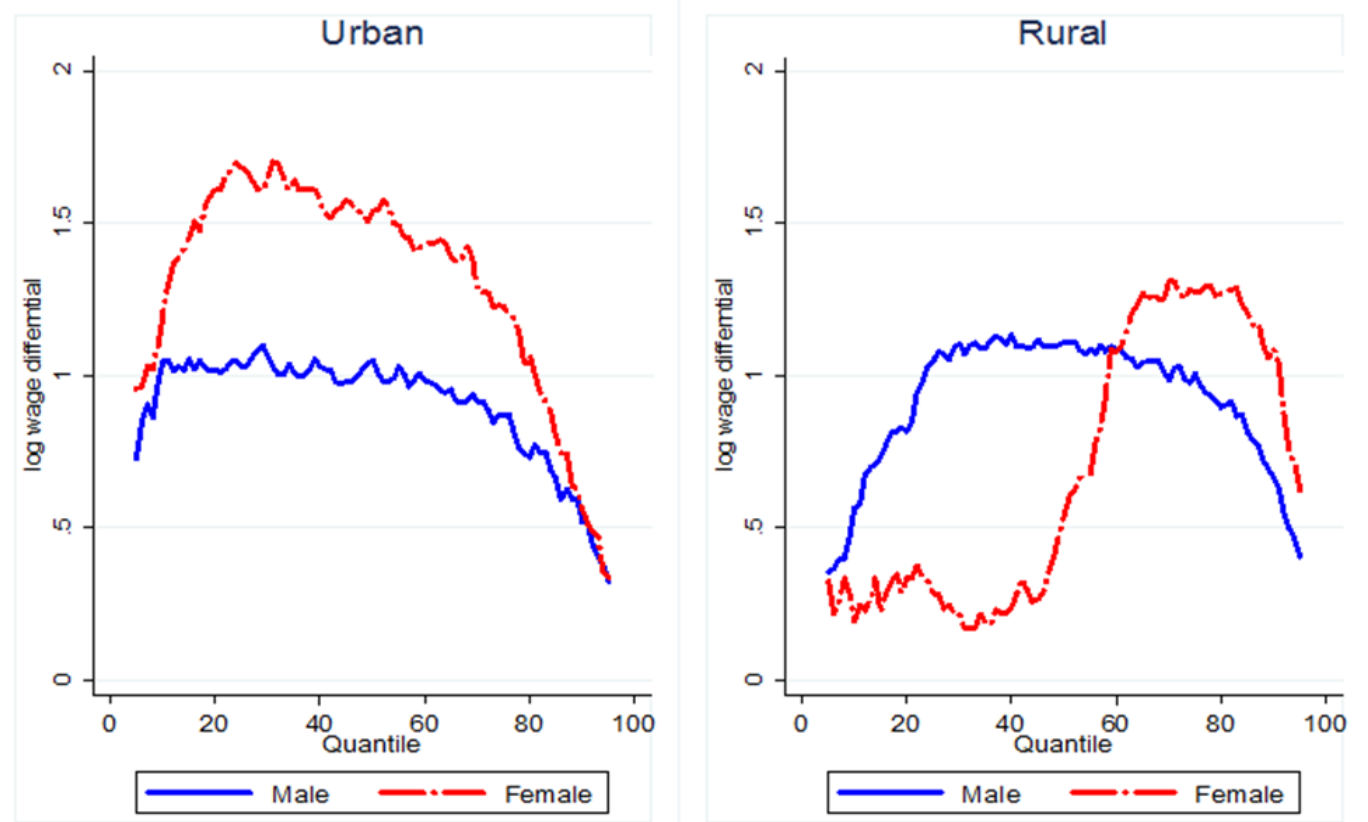
Figure 4: Decomposition of public-private wage differential, Urban India
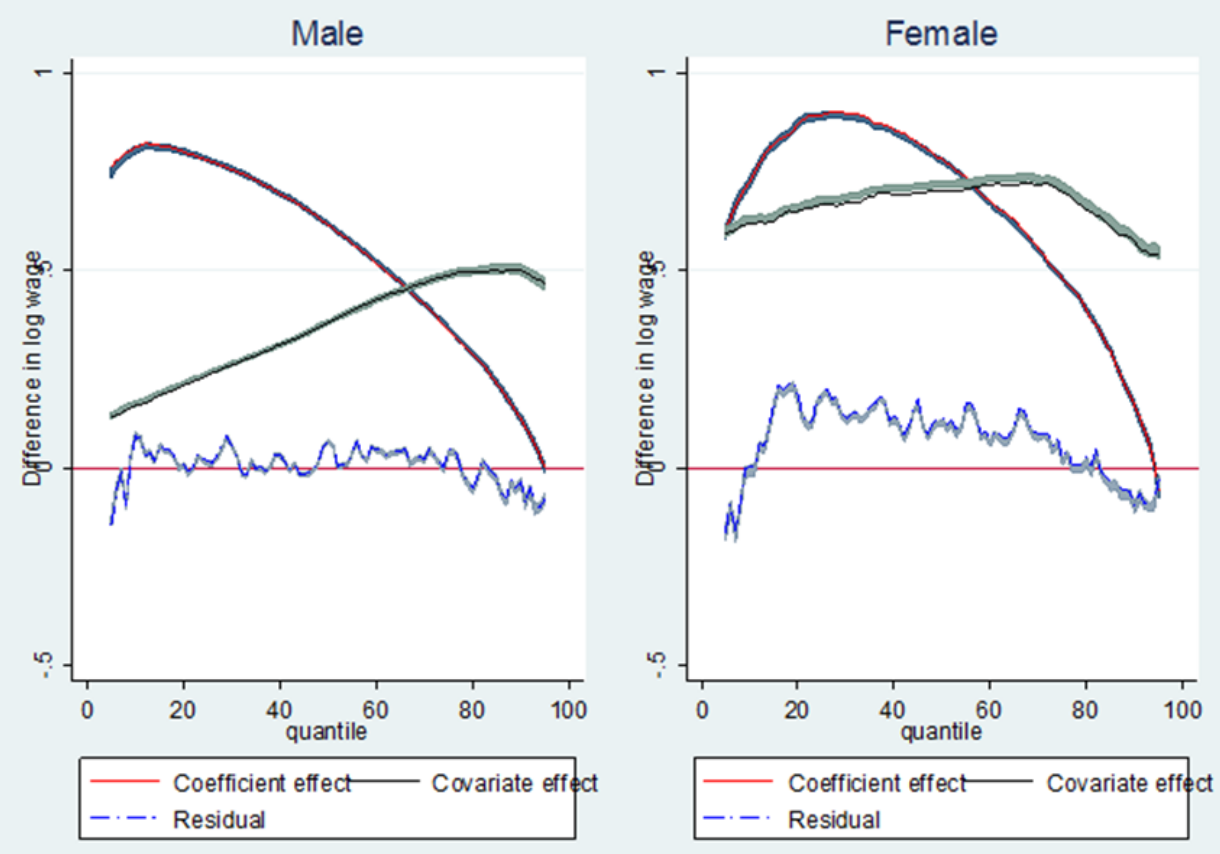

Figure 5: Decomposition of public-private wage differential, Rural India
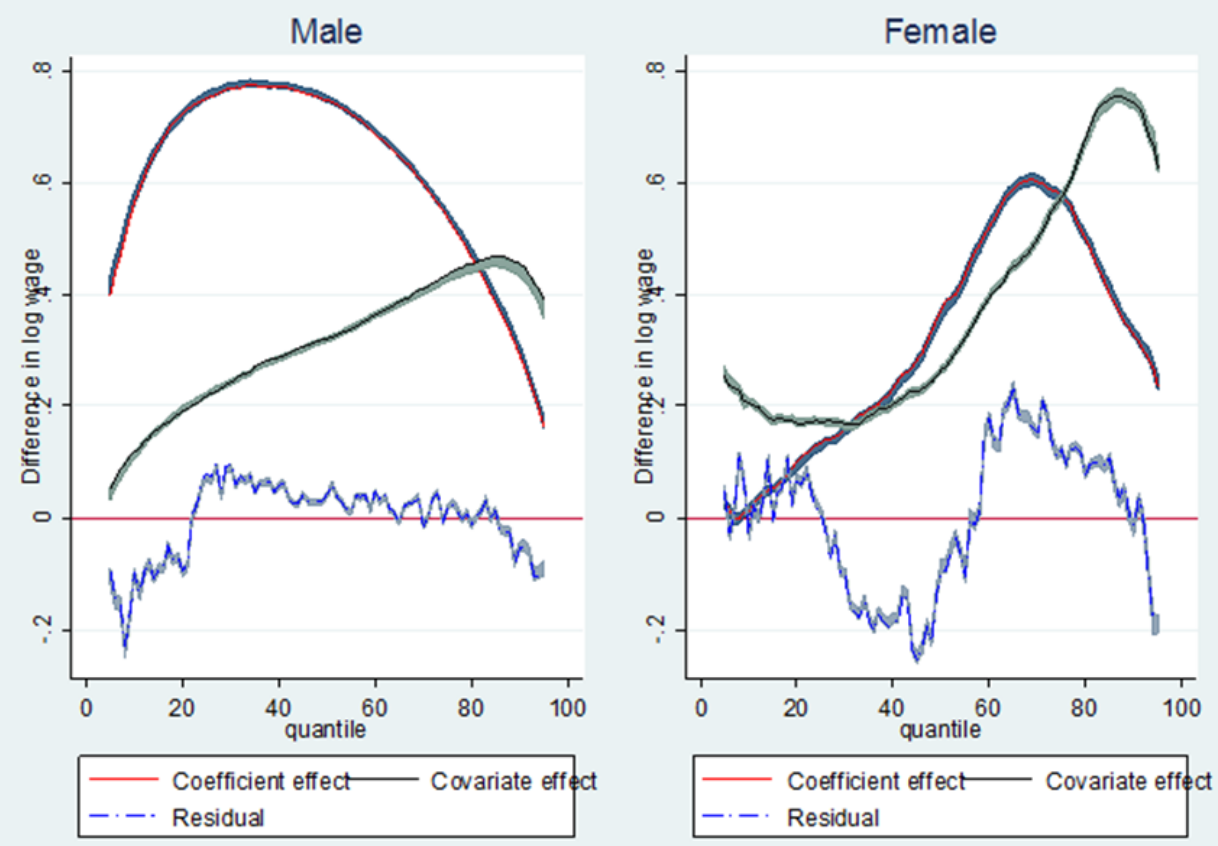